\title{
ANALYSIS OF AMPLIFICATION OF STUDENT CHARACTER IN THE SCHOOL ENVIRONMENT
}

\author{
Fajar Wulandari ${ }^{1}$, Dina Anika Marhayani ${ }^{2}$ \\ ${ }^{12}$ Elementary School Teacher Education, STKIP Singkawang \\ E-mail: fajarwulandari3@gmail.com
}

\begin{abstract}
This study aims to strengthen the character of students in maintaining environmental cleanliness, especially in schools. Strengthening of students is needed to be more loving and caring for the environment, thus students can implement positive attitudes wherever they are. This research was conducted at SDN 5 Singkawang. An environmentally friendly school that applies the characteristics of caring for the environment as an effort to manage and preserve the environment. Recycling activities are activities carried out to aim to support the application of environmental care characters to all elements of students in the school. The method used in this study uses a descriptive qualitative approach. data source sampling is done purposively and snowball, collection techniques with triangulation (combined) data analysis are inductive and qualitative, and the results of qualitative research emphasize the meaning rather than generalization. Students character is needed to overcome the problems faced by this country, one of which is the problem of environmental damage. Through methods that directly plunged into spaciousness such as the outdoor method the researchers also applied it to students of SD Negeri 5 Singkawang and it was also proven that the outdoor method was known to improve students' understanding and character of caring for the environment, by throwing trash in the trash and always washing their hands after doing activities in outdoor.
\end{abstract}

Keywords: Character, Outdoor Study, Environment

\section{A. INTRODUCTION}

According to Law No. 32 of 2009 (Undang-Undang Nomor 32 Tahun 2009 Tentang Perlindungan Dan Pengelolaan Lingkungan Hidup, 2009), concerning Environmental Management says that: the environment is a unity of space with all objects, power, conditions, and living things, including humans and their behaviour, which affect nature itself, the continuity of life, and the well-being of humans and other living creatures. Human life is closely related to the environment but still lacks a sense of concern and responsibility for the environment, so it is necessary to apply character education to care about the environment. Living things can meet all the needs of life from the environment such as natural resources that are used by people as a satisfying needs, but this has not been matched with knowledge and a sense of responsibility towards nature so that many natural damages start from land, water, and air that cause problems environment. 
School is an institution that manages and organizes education and teaching to students in an effort to achieve the expected goals and is a powerful place in building intelligence, attitudes and skills of students in facing the realities of their lives (Munadlir, 2016). Schools that have received the title of adiwiyata are considered has succeeded in shaping the character of caring for the environment (Al-anwari, 2014). This is known from several previous studies, including those conducted by Andar Abdi Saragih who suggested that there is a positive influence from the adiwiyata program on the cognitive, affective, and psychomotor environment of students in conducting interactions with all school residents who have different backgrounds such as: ethnicity, culture, socioeconomic level, customs, gender, religion.

Education is one of the factors that play a role in the formation and change of the character of each person. This was also stated by (Abidinsyah, 2011) that character is not formed by itself, but must be shaped and developed through education. Therefore, character education is an effort that must be done by Indonesia. (Asmani, 2011) suggests the purpose of character education which is meant by students' self-assessment and renewal of life order that is more individual freedom, as well as improving organizational competence and educational outcomes in schools that lead to character development and morality or morals that are lucky for students by intact, integrated, and balanced by the combined competency standards. Through character education, it is hoped that it can be educated independently to improve and use its knowledge, study and internalize and personalize the values of character and noble character so that it is manifested in everyday relationship.

Character education also needs to be applied to students to form identity and have a positive influence. Character education in the school environment is expected by many parents of children due to a growing social phenomenon that is increasing juvenile delinquency in society, mass fights, rape, theft and various other cases of moral degradation committed by children who are still in school (Wathoni, 2014).

Learning done in the learning process will be easily channelled intents and objectives of the teacher uses the learning method or model. The outdoor method is a method that is suitable for use in the learning process. Outdoor Study Method is a method where the teacher invites students to study outside the classroom to see live events in the 
field to familiarize students with their environment (Husamah, 2013). The role of the teacher here is as a motivator, meaning the teacher as a guide so that students learn actively, creatively and familiar with the environment.

Learning outside the classroom (outdoor study) is one of the learning methods where learning activities take place outside the classroom/school such as; parks, villages, gardens and others to the aim to involve direct experience and challenge the spirit of adventure of students to be more familiar with the environment and society (Riadi, 2019). The method of learning outside the classroom is an effort to get closer to real learning resources, namely nature and society. Students are directed to do activities that can bring them to behaviour changes in the surrounding environment. According to (Baharuddin \& Wahyuni, 2010), learning outside the classroom can be done in several steps which begin with a) the stages of real experience is the process in which students experience the experiences they have experienced directly when they go directly into the field or the surrounding environment. b) relative observation stage is an active student who will be able to make observations by looking for answers and thinking about the tasks and hall they have to do. Understanding that students get directly can develop student abilities, to facilitate the percentage of teaching and learning. c) conceptual stage is the process of student learning to make abstractions in developing knowledge through reading theory or explanation that is appropriate for elementary school children, through observing the events that occur in their immediate environment. Based on this stage each student will give a different response. d) the implementation phase is the last stage that will be undertaken by students. Students actively conduct experiments and apply theories or rules that apply students are invited to think deductively in solving a problem or environmental case.

The character of caring for the environment is an attitude of caring for the environment which is manifested in the willingness to express actions that can improve and maintain the quality of the environment in every behavior related to the environment. Cultivation of the character of caring for the environment through waste disposal activities in place and the activity of one day clean waste. Character is closely related to someone's personality. Someone can be said to have character (a person of character) if the behaviour is following moral rules. Based on this understanding, it can be understood that 
the characters are the mental, behavioural, and individual characteristics that characterize the individual.

The environment is a union of space with all objects, power, conditions, living things, including humans, and their behavior that affects the survival and well-being of humans and other creatures. The environment is also a whole system, the collectivity of a series of interconnected, interdependent and functional subsystems of one another, thus forming a unified whole ecosystem (Ulum, 2017). The environment is a combination of physical conditions including the condition of natural resources (natural resources) such as land, water, solar energy, minerals, and animals and plants that grow on land and at sea, with various institutions that include the creation of humans as decisions on how to use the physical environment (Ilham, 2020). In addition, the environment can also be interpreted into everything that is around humans and one of them influences the development of human life.

This environmental care character is needed to overcome the problems faced by this country, one of which is the problem of environmental damage. This environmental problem is triggered by the lack of students' care for their environment, so many problems arise from students who do not care about the environment, more specifically in the school environment. Students who do not care automatically do not have a strong character in protecting the environment, because it can cause a variety of damage to the environment around not only schools but also will have an impact on the community environment.

Strengthening skills provided by the teacher, then students will feel compelled forever to give a response every time a stimulus appears from the teacher, or students will try to avoid responses that are considered not useful. Functions skill reinforcement (reinforcement) that is to give a reward to students so that students will be encouraged and increase their participation in each of the learning process.

Meanwhile, according to research for (Umam, 2018), one of the routine activities that can be done to improve students' character in an environmentally conscious attitude is to support the application of environmental education such as on Friday the activities of the ant forces (cleaning activities) of the school or for students who are religious Muslims can do routine Friday prayers so that they can increase students' faith, 
with teachers who play an active role in giving influence or good examples for students.

Based on observations while in school, the lack of diversity in the methods teachers use when teaching affects learning outcomes. This is supported also by the lack of active students and their inadequacy in overcoming problems or learning cases given to students in schools, especially in the class. Characteristics of children who need to be instilled a sense of environmental care. Cultivation of a caring attitude towards the environment needs appropriate methods so that children are motivated to do so, that's what underlies the use of outdoor methods. Some things are done like:

1. Disposing of trash in its place Disposing of garbage in its place which is a program or activity which is one of the program activities for civilizing the character of environmental care in the school environment. This activity civilizes all school officials and students to throw garbage in the trash. Previously, garbage was divided into two, namely: wet waste and dry waste. Wet waste is disposed of in a blue trash bin, while dry waste is disposed of in a yellow trash can. With guidance and guidance carried out by the teacher, the activities can be done well.

2. Conduct clean waste day activities One day clean rubbish activity is an activity that can be done in every elementary school, where every week there is a day to clean up the school environment. Activities like this can be done by:

a) Taking/collecting garbage and then killing the landfill to be burned

b) Burning waste from materials that are not easily decomposed by soil

c) Sorting out waste that might still be made by hand or by recycling.

3. Make Sweeping Schedules

Making a sweeping schedule for each class may have become a common activity that is always carried out in every school, both elementary, secondary and advanced levels. By creating a class sweeping schedule that is implemented in elementary schools should be able to provide the main capital for children to make the room always clean. By providing this sweeping schedule, children have the responsibility to keep their classrooms from trash or dust which can hamper the learning process because the room is uncomfortable. In giving this schedule, what needs to 
be considered is the gender aspect, because it is not uncommon to find boys who tend to be lazy in sweeping this class. Therefore, heterogeneous (mixed) groupings need to be formed, wherein the sweeping list group there are boys and girls not based on service. With habits like that the child is always accustomed so that in the end the child will do it not only in the school environment. Activities to familiarize the environment clean is one of the activities that can instil an attitude of caring for the environment so that the environment becomes well-groomed, clean and healthy. A clean and healthy environment will make every individual who is in the environment will also be healthy. So that in the end, the learning process becomes comfortable and conducive.

The implementation of environmentally friendly character education is often packaged in an environmentally friendly school. Likewise, SDN 5 Singkawang Tengah as environmentally friendly schools applying the character of caring for the environment as an effort to manage and preserve the environment. Recycling activities are activities carried out to aim to support the application of environmental care characters to all elements of students in the school.

\section{B. MATERIALS AND METHODS}

This study uses descriptive research that is research that describes the actual state of an object. According to (Sugiyono, 2016), descriptive research is research conducted to determine the existence of the value of an independent variable, either one or more variables without making comparisons or relationships with other variables. This study intends to describe the strengthening of the character of environmental cleanliness. This research was conducted at SDN 05 Singkawang Tengah, in class VI. In this study, interviews were also conducted with students and principals as well as related parties, and attach documentation that could strengthen the purpose of this study. In the order hand, outdoor study also can help process learning of our class. Students are invited directly to the field or out of class to pay attention to the environment and provide cases related to environmental problems such as garbage in the school environment, then students will provide solutions and their opinions. This is to stimulate students' thinking power to solve trash cases in the school environment. 


\section{RESULTS AND DISCUSSION}

This study describes the results of interviews from several informants to get the data needed. The informants in this study were the vice-principal, grade VI teachers. The first informant that we interviewed was the Deputy Principal named Hamdie, S.Pd, .SD and the class teacher named Maryani, S.Pd,. SD as a class VI teacher, he was made the main information for interviews about the issues to be studied, because he knew characteristics of class VI students.

\section{Observation Data Findings}

1) Teacher Observation

a) Saying according to reality

The teacher invites students to do ant operations and clean the environment every Friday morning. The teacher invites students to always wash their hands after doing activities.

b) Teaching to admit mistakes

The teacher always reminds students that they are guilty should apologize and gives a direct reprimand when students who throw garbage that does not enter the trash. This can be seen when the teacher reprimands one of the students who are guilty of admitting their mistakes and apologizing. c) Modelling uniforms by the provisions

Teachers set an example in neat uniforms and following the provisions. Looks neat uniform, the hijab worn without any colour and according to the colour of the shirt, then the teacher uses loafers.

d) Teaches to behave politely

Politeness is behaviour under ethics. This is taught by the teacher by always motivating so that students do not stare and do not speak out loud while talking, and respect others who are older. If students are not polite the teacher immediately reprimands and advises the student.

e) Disposing of trash in its place

Before entering the class the teacher who teaches asks students to pay attention to their surroundings if there is teacher waste and the students pick up the trash and then throw it away in the place provided.

f) Teach plastic recycling

Teachers teach students to recycle used sparrows into flower shapes and make plastic bottles that have been cleaned into small plant pots. 


\section{Student Observations}

a) Always say according to reality

Students throw trash in their place, but sometimes students still throw trash in their place.

b) Want to admit mistakes when guilty and apologize

Students reprimanded by the teacher and throw the trash in its place students immediately carry out the teacher's order to dispose of trash in its place.

c) Wearing uniforms according to the rules and neat

Students use belts and clothes to get into, but there are some students whose clothes are still out.

d) Children behave politely with those around them

When the observation team enters the class, students come to us to greet and shake hands.

e) Disposing of trash in its place

Students become accustomed to throwing rubbish in their place even though they are in the canteen but the school still provides rubbish bins in the canteen and some students bring their trash from the canteen to the trash where they are met in front of the nearest class.

\section{Findings Interview Data}

Based on the presentation of the results of the interviews the exemplary forms that the teacher uses to shape the character of students is an example of discipline, develops student creativity, develops a noble character, and accustoms good things starting from simple ones so that students do good habits.

\section{Documentation}

The technique is used to obtain supporting data. Documentation is carried out to obtain data related to the implementation of the program of strengthening the character of environmental cleanliness. Location of SDN 5 Singkawang Tengah documentation, in class VI. Under this activity students in strengthening the character to maintain cleanliness and care for the environment.

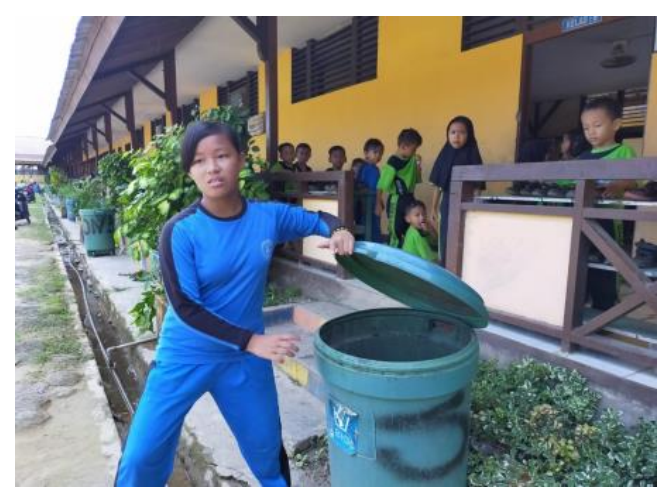

Figure 1. Disposing Student Activities Rubbish 
Based on picture 1. Student Activities Disposing of Garbage explained that the activity of disposing of garbage in the trash to instil the strengthening of character in protecting the environment from the garbage.

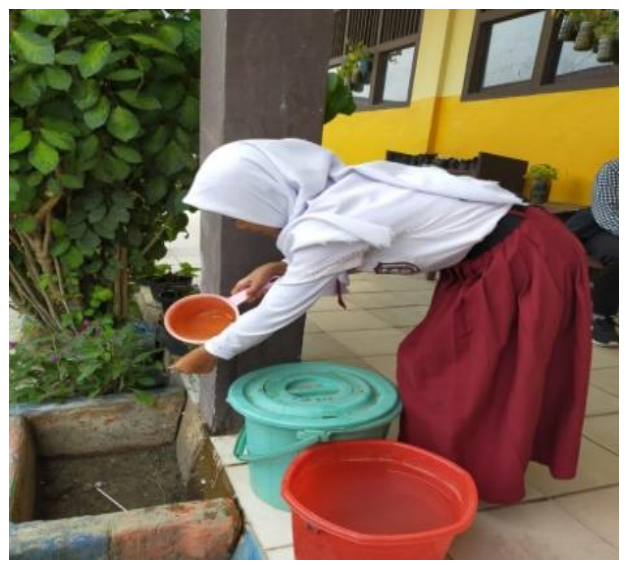

Figure 2. Student Activities Watering Plants

In Figure 2. Describe that the activity of watering plants is a good character and must be applied as early as possible because the activity of caring for plants is also the activity of caring for fellow living beings.

Activities carried out by the teacher with students to keep the environment maintained, namely, ant operations, cleaning the school environment every Friday, checking students' nails and hair, and informing students to wash their hands before touching food. So that students are accustomed to caring for personal hygiene and the environment. The plan for environmental maintenance in addition to ant operations and caring for personal hygiene, the teacher teaches students in utilizing plastic waste into a work that has beauty and use. The attitude of caring for the environment has been adopted by students in SDN 05 Singkawang Tengah.

\section{CONCLUSIONS}

Environmental care character is needed to overcome the problems faced by this country, one of which is the problem of environmental damage. This environmental problem is triggered by the lack of students' concern for their environment, so many problems arise from students who do not care about the environment, more specifically in the school environment.

Efforts to protect the environment, even though students on average obey the rules, there are still some students who still need to be reprimanded first. The benefit of preserving the environment for the community is the creation of a clean and original environment. The plan for environmental maintenance in addition to ant operations and caring for personal hygiene, the teacher teaches students in utilizing plastic waste into a work that has beauty and use. The attitude of caring for the environment has been adopted by students at SDN 05 Singkawang Tengah. 


\section{E. REFERENCES}

Abidinsyah. (2011). Urgensi Pendidikan berkarakter dalam Membangun Peradaban Bangsa yang Bermartabat. Jurnal Socioscienta, 3(1).

Al-anwari, A. M. (2014). Strategi Pembentukan Karakter Peduli Lingkungan Di Sekolah Adiwiyata Mandiri. Ta'dib, 19(02), 227-252.

Asmani, J. (2011). Buku Panduan Internalisasi Pendidikan Karakter di Sekolah. Diva Press.

Baharuddin, \& Wahyuni, E. (2010). Teori Belajar dan Pembelajaran. Ar-Ruzz Media.

Husamah. (2013). Pembelajaran Luar Kelas Outdoor Learning. Prestasi Pustaka.

Ilham, M. (2020). Pengertian Lingkungan adalah - Penyebab, Dampak, Pencegahan. Materi Belajar.Co.Id.

https://materibelajar.co.id/pengerti an-lingkungan-adalah/

Munadlir, A. (2016). STRATEGI SEKOLAH DALAM PENDIDIKAN

MULTIKULTURAL. Jurnal Pendidikan Sekolah Dasar, 2(2), 114-130.
Undang-Undang Nomor 32 Tahun 2009 tentang Perlindungan dan Pengelolaan Lingkungan Hidup, Peraturan Pemerintah (2009).

Riadi, M. (2019). Metode Pembelajaran di Luar Kelas (Outdoor Study). Kajian Pustaka.Com. https://www.kajianpustaka.com/20 19/09/metode-pembelajaran-diluar-kelas.html

Sugiyono. (2016). Metode Penelitian Kuantitatif, Kualitatif dan $R \& D$. Alfabeta.

Ulum, B. (2017). Internalisasi Karakter Peduli Terhadap Lingkungan di SMAN 4 Kota Pasuruan. UIN Malang.

Umam, K. (2018). Implementasi Pendidikan Lingkungan Hidup Pada Sekolah Adiwiyata Mandiri SDN Dinoyo 2 Kota Malang [UIN Malang]. http://etheses.uinmalang.ac.id/13371/1/12140096.p df

Wathoni, K. (2014). KARAKTER DI PERGURUAN TINGGI: Studi Kasus di Jurusan Tarbiyah STAIN PONOROGO. Didaktika Religia, 2(1), 1-20. https://jurnal.iainkediri.ac.id/index .php/didaktika/article/view/130 